Vol. 4, No. 02; 2021

ISSN: 2581-4664

\title{
THE EFFECT OF WORK ENVIRONMENT AND DEMOCRATIC LEADERSHIP ON JOB SATISFACTION AND ITS IMPLICATION ON WORK DISCIPLINE OF PIDIE JAYA DISTRICT PUBLIC WORKS OFFICE
}

\author{
*Rizal Fikar, Mukhlis and Said Musnadi \\ Management Department, Universitas Syiah Kuala, Indonesia \\ http://doi.org/10.35409/IJBMER.2021.3249
}

\begin{abstract}
Purpose

This study aims to examine the influence of the work environment, democratic leadership on job satisfaction, and its implications for the work discipline of Public Works officials in the Pidie Jaya district. Hypothesis testing is carried out directly and indirectly to see the effect of exogenous variables on endogenous

Design/Method

The population in this study were all employees, both civil servants and contract employees at the Public Works Office of Pidie Jaya District, totaling 139 people. The research sample was taken as a whole (census). The research model was analyzed using Structural Equation Modeling (SEM).

Findings and Originality

The results of direct hypothesis testing show that the work environment has a significant effect on job satisfaction (H2), democratic leadership has a significant effect on job satisfaction (H3), work environment has no significant effect on work discipline (H4), democratic leadership has a significant effect on work discipline (H3). H5) and job satisfaction has a significant effect on work discipline (H6). The results of indirect hypothesis testing show that the work environment has no effect on employee work discipline through job satisfaction $(\mathrm{H} 7)$, and democratic leadership has a significant effect on employee work discipline through job satisfaction (partial mediation) (H8).The originality lies in the research model that combines theprevious models with democratic leadership variable in Pidie Jaya District Public Works Office.

Implications and Recommendations

The presence of democratic leadership at the Public Works office in Pidie Jaya Regency has proven to be very much in need of strengthening so that it can improve work discipline of its employees. The policy-making authority in the organization must always monitor the level of work discipline of its employees both administratively and directly. For further studies, the researchers recommend conducting further testing to improve work discipline by using work motivation, expertise, work relations, and knowledge sharing variables.
\end{abstract}

Keyword:Work Environment, Democratic Leadership, Job Satisfaction, Work Discipline

\section{INTRODUCTION}

The Public Works Office (or locally in Indonesia is known as a Dinas P.U) of Pidie Jaya 


\section{International Journal of Business Management and Economic Review}

Vol. 4, No. 02; 2021

ISSN: 2581-4664

District is an agency under the umbrella of the Pidie Jaya District Government (PemkabPijay). The smooth running of national development in the administration of government is highly dependent on the perfection of the State apparatus. In an effort to achieve organizational goals, the performance of the State civil servants (ASN) in the PijayDistrict Government's Public Works Office is required to be able to display their performance optimally to provide more satisfying services to the community. This is because ASN has a very important role in development to create a civil society. If the ASN in an agency is bad, then the objectives of the agency cannot be achieved as planned.

The success of an organization, in this case government agencies, is greatly influenced by work discipline. Work discipline is marked by various things related to employee behavior. Discipline is an important behavior that must be possessed by ASN in realizing organizational goals. In running the government, work discipline is an absolute that must be applied by ASN. This is stated in Law No. 53 of 2010 concerning Civil Servant Discipline. Theoretically, there are several reasons and sources that encourage employees to be undisciplined in their work as expressed by(Kular, Gatenby, \& Rees, 2008) and (Mukhalipi, 2018) that are External environment causes, Psychological source causes, Organizational causes, and other sources.

The issue of work discipline among ASN is an issue that needs to be given serious attention because this will greatly impact the achievement of regional development goals and national development goals. Phenomena that often occur in the PijayDistrict Government related to work discipline are violations of working hours (delays), leaving work prematurely, leaving the office without permission, hanging out in coffee shops/canteens during working hours, wandering during working hours with still wearing official clothes, violations of absenteeism, and abuse of authority. This causes obstruction of the achievement of organizational goals and has a negative effect on the organization.

In an effort to address disciplinary violations, the government has made many efforts, including implementing strict policies, rewarding outstanding civil servants, and imposing punishment for employees who obey the established regulations. However, until now these steps have not produced optimal results with many civil servants who have not heed these regulations in their behavior or have not shown any changes. This can be seen from the many cases and phenomena of absenteeism from work and other violations of work discipline committed by ASN.

Departing from the phenomena above, the researchers conducted an initial survey involving 25 employees of the Pijay District Government's Public Works Office regarding work discipline. The survey results showed that the work discipline of employees carried out by the employees of the Public Works Office of Pidie Jaya District was not optimal. This indicates that there should be stronger efforts by the offices and local governments to improve employee discipline by providing an understanding that the best possible discipline must be instilled in every civil servant. To obtain good work discipline, ASN must obey the rules of the time, government regulations, work behavior, and other rules as stipulated both by the service, local government, and regulations regarding the civil apparatus of the Republic of Indonesia. Good discipline reflects a person's sense of responsibility for the tasks assigned to him.

The low discipline of employees in the Public Works Office of Pidie Jaya District as found in this initial survey can be seen at the time of entering work, there are still employees who arrive late from the stipulated rules, namely 08.00 a.mand even go home too early from the 


\section{International Journal of Business Management and Economic Review}

Vol. 4, No. 02; 2021

ISSN: 2581-4664

stipulated regulation at $05.00 \mathrm{p} . \mathrm{m}$, break time work determined by the agency is often violated by coming back to the office beyond the stipulated break time limit and various other disciplinary violations that often occur and receive reprimands from their respective superiors.

The factor that affects employee work discipline is job satisfaction. Employees who are not satisfied with the agency tend to give mediocre performance and even lower than expected. In order to realize the vision and mission of the service and the vision and mission of the Regent of Pidie Jaya District, the Pidie Jaya DistrictPublic Works Office demands high work discipline for its employees. Of course, this must be balanced with providing satisfaction to all employees by meeting the needs and expectations of employees. The results of the initial survey show that there are three satisfaction indicators that still have a value below the average satisfaction score. This indicator is related to the rewards received by employees, work relations with fellow employees and respect for each other.

The factors that influence job satisfaction and have an impact on work discipline are democratic leadership factors. Leadership is the backbone of organizational development because without good leadership it will be difficult to achieve organizational goals, even to adapt to the changes that are taking place inside or outside the organization. Choosing the right leadership style to direct and manage employees is difficult because leaders have heavy responsibilities. One of the leadership styles that have been believed to be able to encourage job satisfaction in an organization is democratic leadership. Another factor that affects job satisfaction and has an impact on work discipline is the work environment. The work environment is everything that is around the workforce and can affect him in carrying out the tasks assigned to him. Broadly speaking, the work environment is divided into two, namely the physical work environment and the non-physical work environment.

Seeing the various phenomena of discipline and employee satisfaction that occur in the work environment of the Public Works Office of Pidie Jaya District, the authors were interested in conducting a comprehensive research about The Effect of Work Environment and Democratic Leadership on Job Satisfaction and Its Implications on Work Discipline of Pidie Jaya DistrictPublic Works Service Employees. This research is based on several previous studies, both domestic and foreign, as conducted(Astuti, Aunurrahman, \& Wahyudi, 2019), (Mitang \& Kiha, 2019), (Sasandaru, 2018), (Kristianto, 2018), (Rafiie, Azis, \& Idris, 2018), (Husni, Musnadi, \& Faisal, 2017), (Agbozo, Owusu, Hoedoafia, \& Atakorah, 2017), (Angraini, Syaharudin, \& Apriono, 2016)and(Chandra \& Priyono, 2016). Of all the studies that have been conducted and quoted in this study, no research has been found that examines the role of job satisfaction in moderating the work environment, democratic leadership on the work discipline of employees of the Public Works Office of Pidie Jaya District.

This research is more focused on the standard of work discipline of employees in carrying out their duties at the Public Works Office of Pidie Jaya District which is not maximized in their performance achievements. In this study, the researchersneed to prove whether the variables of the work environment and democratic leadership affect job satisfaction, either directly or indirectly at the Public Works Office of Pidie Jaya District. The research model is a combination of the previous models which are integrated based on facts that occur in the field.

\section{LITERATURE STUDY Work Discipline}




\section{International Journal of Business Management and Economic Review}

Vol. 4, No. 02; 2021

ISSN: 2581-4664

In carrying out their performance and achieving the goals of an organization, employees are required to comply with applicable standards including work discipline. A phenomenon that often occurs in the work environment is employee work discipline, matters regarding work discipline need to be followed up more seriously by company management so that the goals and performance of employees are right on target, especially in the employee environment. In carrying out their daily duties, there are still many employees who violate work rules and discipline. This is reflected in not achieving the maximum targets set by the government in an effort to increase national development, thus creating a bad view of the community.

To improve employee work discipline in order to achieve the goals of an organization, company management or the leader of an organization needs to make special efforts and special monitoring of employee work discipline so that employees do not violate the rules or norms that apply in the company environment. In other words, work discipline is an individual's attitude in obeying and complying with the rules and/or provisions set in the work environment.(Sinungan, 2018)defined work discipline as the psychological attitude of a person or group of people who always desire to follow/obey all the rules or decisions that have been set.

In his book(Hasibuan, 2016)stated that work discipline is the awareness and willingness of a person to obey all company regulations and prevailing social norms. Work discipline requires a communication tool as a specific warning for employees who do not want to change their nature and behavior. In accordance with the results of research conducted by(Kristianto, 2018)which mentioned work discipline is as a tool used by leaders to communicate with employees in order to increase one's awareness and willingness to comply with all company regulations and prevailing social norms.

Many factors influence work discipline, one of which wasstated by(Hasibuan, 2016)was the goals \& abilities, role models of leaders, remuneration, justice, inherent supervision, sanctions, assertiveness, human relations. In addition, job satisfaction factors also affect employee work discipline. This is evidenced by the results of research conducted by(Ilahi, Mukzam, \& Prasetya, 2017), (Sari, Siburian, \& Wau, 2017), (Hadian, 2019)where they prove that the job satisfaction factor has a positive and significant effect on employee work discipline. Besides the job satisfaction factor, (Suwuh, 2015), (Novitasari, 2017), and (Mitang \& Kiha, 2019)revealed that democratic leadership factors also affect employee work discipline.

Another factor that affects work discipline is the work environment factor. A conducive work environment can improve employee work discipline. Research conducted by(Pawirosumarto, Sarjana, \& Gunawan, 2017)showed that the work environment has a positive and significant effect on work discipline. The same thing is also evidenced by the results of research conducted by(Yugusna, Fathoni, \& Haryono, 2016)which stated that work environment factors have a positive and significant effect on employee work discipline. Measurement of work discipline in this study uses indicators as disclosed by(Soetrisno, 2016)namely obeying the rules of time, obeying the rules and regulations in force, obeying the rules of conduct at work, loyal and obedient to superiors, and always keeping time.

\section{Job Satisfaction}

The satisfaction that each person feels is different because job satisfaction is the level of pleasure or happiness obtained as a result of an assessment of the work that has been done. Therefore, job satisfaction is one of the research variables that are observed in company 


\section{International Journal of Business Management and Economic Review}

Vol. 4, No. 02; 2021

ISSN: 2581-4664

psychology. (Robbins, Coulter, \& Cenzo, 2019)defined job satisfaction as a general attitude towards a job that results from a difference between what is received and what is believed to be received from a job. Meanwhile(Judge \& Mueller, 2012)mentioned job satisfaction as an assessment that expresses satisfaction and positive feelings about one's job.

Job satisfaction is one of the work attitude variables, this variable measures employee satisfaction with their work. Job satisfaction can be measured through the cognitive (evaluative), affective (emotional), and behavioral components. The researchers also noted that measures of job satisfaction varied depending on the degree to which they measured feelings about work (affective job satisfaction) or cognition about work (cognitive job satisfaction). Based on the understanding of several authors regarding job satisfaction, it can be concluded that the notion of job satisfaction is a feeling or a positive emotion felt by employees regarding their job appraisal where the results obtained are in accordance with expectations.

In his book (Robbins \& Judge, 2012)mentioned when people talk about employee attitudes, then what is meant is job satisfaction which describes the positive feelings of an employee towards his job. Employees with a high level of job satisfaction will also have positive feelings towards their work, while employees who have a low level of satisfaction will generate negative feelings about their work. then(Robbins \& Judge, 2012)also argued that the indicators of job satisfaction include: happiness felt by employees due to financial and non-financial factors, relationships with colleagues in an office environment, employee relations with organizational leaders, employees are able to overcome the dishonesty in the office, employees have an attitude of respect for others colleagues, and employees are given opportunities to develop.

(Mangkunegara, 2013)revealed that there are 2 factors that influence job satisfaction, namely employee factors and job factors. Meanwhile(Robbins \& Coulter, 2016)disclosed factors that can lead to job satisfaction are mentally challenging work, appropriate rewards, supportive working conditions, and supportive coworkers. In addition to the factors that have been expressed by these experts, many researchers also reveal that the factor that affects job satisfaction is the democratic leadership style. This is evidenced by the results of research conducted by(Suryaningsih, 2017), (Dyczkowska \& Dyczkowski, 2018), (Mitang \& Kiha, 2019)where their results proved that democratic leadership has a significant effect on employee job satisfaction.

In addition, work environment factors also affect employee job satisfaction. This was evidenced by(Aulia, Musnadi, \& Faisal, 2019), (Wani, Adam, \& Majid, 2018), (Rafiie, Nasir, \& Sofyan, 2018), (Kurniawan, Mukhlis, \& Musnadi, 2020), and (Munandar, Musnadi, \& Sulaiman, 2019). In their research, they prove that the work environment has a positive and significant effect on employee job satisfaction, both physically and non-physically. Therefore, the management or company leadership must pay special attention to the conditions of the work environment.

\section{Work Environment}

The work environment is where workers carry out their activities. The work environment can have a positive or negative impact on employees in carrying out their work. According to(Sedarmayanti, 2016)an employee is able to carry out his activities well, so that an optimal result is achieved if supported by an appropriate working environment. The work environment 


\section{International Journal of Business Management and Economic Review}

Vol. 4, No. 02; 2021

ISSN: 2581-4664

can play an important role in the quality of employee work(Potu, 2013).In his research(Dwinguspana, Sumari, \& Prihantoro, 2016)explaining the work environment is everything that is around the work area and can affect him in carrying out the tasks assigned to him.

A conducive environment will have a positive impact on the continuity of work, while an environment that is not conducive will have a negative impact on the continuity of work(Pawirosumarto et al., 2017). A conducive work environment can also be caused by internal and external factors. The work environment will more or less affect the physical and psychological aspects of employees when doing their work. Therefore, it is very important for leaders to create a work environment that can make employees work efficiently and effectively and minimize the possibility of employees getting injured while doing their work.

Indicators of the work environment used in this study are as disclosed by(Handoko, 2003) in (Rafiie, Nasir, et al., 2018)namely lighting, trust in the workplace, temperature at work, humidity at work, air circulation at work, noise at work, odors at work, color arrangement at work, decoration at work, music at work and security at work. work. This indicator was chosen because it is very feasible and can describe the work environment in the Pijay District Government's Public Works Office.

\section{Democratic Leadership}

Leadership in an organization is an important factor in determining the achievement of the goals set by the organization. A leader is a person who has responsibility for decision making, running policy direction, supervising, motivating, communicating and directing subordinates in running an organization so that they can achieve the goals and objectives of the organization.(Northouse, 2013)expressing leadership style is a set of characteristics used by leaders to influence subordinates in achieving organizational goals or objectives. The following are kinds of leadership styles, namely authoritarian leadership styles, democratic leadership styles, free leadership styles, continuum leadership styles, effective leadership styles and situational leadership styles.

At the Public Works Service, the PijayDistrict Government applies a democratic leadership style in running its wheels of government. Democratic leadership style is one of the leadership styles that are widely used and always coveted in an organization(Thoha, 2012). While(Zainal, 2015)defined a democratic leadership style as the ability to influence others to be willing to work together to achieve predetermined goals by means of the various activities that will be carried out are determined jointly between the leader and subordinates. Democratic leadership style is considered as the most appropriate leadership style, because it requires leaders who are willing to be directly involved with organizational activities, provide direction and listen to suggestions or input from their subordinates, are very concerned about the interests and welfare of subordinates, act on subordinates who violate discipline with a corrective and educative approach.

Democratic leaders usually view their role as coordinators and integrators of elements and components of the organization. Leaders position themselves as controllers, regulators and supervisors of the organization by not obstructing the rights of their subordinates to argue(Kobat, Sijabat, \& Safrita, 2018). Under democratic leadership there is bound to be work discipline and work accuracy that is much higher than other types of leadership. The reason is because the group itself dominates the atmosphere. Social pressure and social control exerted by each 


\section{International Journal of Business Management and Economic Review}

Vol. 4, No. 02; 2021

ISSN: 2581-4664

member of the group on other fellow members forces all members to behave in accordance with group norms. (Thoha, 2012)expressed democratic leadership style can be measured using indicators: the leader is willing to accept criticism and suggestions from subordinates, the leader gives duties and responsibilities to subordinates, the leader accepts the opinions of subordinates.

\section{Research Model and Hypotheses}

The research model that explains the relationship between each variable on the improvement of work discipline can be figured as follows:

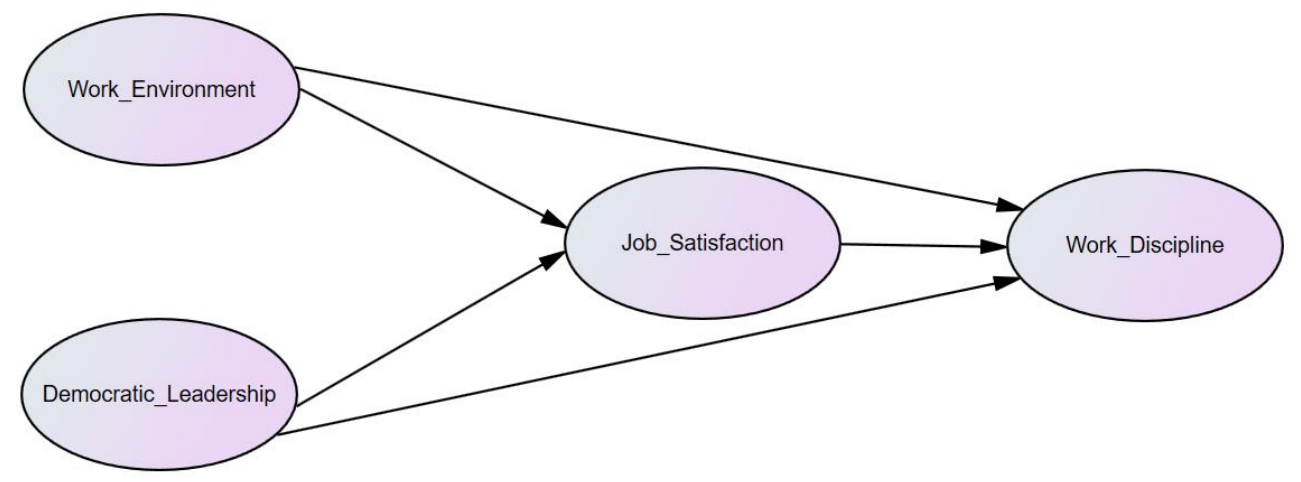

Figure 1.Research Model

Ha1: Work Environment, Democratic Leadership, Job Satisfaction and Work Discipline of Employee of the Public Works Office of Pidie Jaya Districtis good.

Ha2: Work Environment affects the Job Satisfaction of Employee of the Public Works Office of Pidie Jaya District.

Ha3: Democratic Leadership affects Job Satisfaction of Employee of the Public Works Office of Pidie Jaya District.

Ha4: The work environment affects Work Discipline of Employee of the Public Works Office of Pidie Jaya District.

Ha5: Democratic Leadership affects Employee Work Discipline of the Public Works Office of Pidie Jaya District.

Ha6: Job Satisfaction affects Employee Work Discipline of the Public Works Office of Pidie Jaya District.

Ha7: Work Environment affects Work Discipline through Employee Job Satisfaction of the Public Works Office of Pidie Jaya District.

Ha8: Democratic Leadership affects Work Discipline through Employee Job Satisfaction of the Public Works Office of Pidie Jaya District.

\section{RESEARCH METHOD}

This research was conducted at the Public Works Office of PidieJayaDistrict. The research object was the Work Environment, Democratic Leadership, Job Satisfaction, and Work Discipline at the PijayDistrictPublic Works Office. The purpose of this study was to see the direct influence of the work environment and democratic leadership on job satisfaction, the direct influence of the work environment, democratic leadership and job satisfaction on work discipline 


\section{International Journal of Business Management and Economic Review}

Vol. 4, No. 02; 2021

ISSN: 2581-4664

and the role of job satisfaction on the influence of the work environment and democratic leadership on the work discipline of the PidieJayaDistrictPublic Works Office employees. In this study, the population was all employees at the Public Works Office of Pidie Jaya District, amounting to 139 employees consisting of 71 civil servants and 68 contract employees.

Data were collected using a questionnaire method, where the list of questions asked provides answers using a Likert scale. To prove the above hypothesis, researchers used SEM statistical tools with the help of the Amos program. The reason the writer uses the statistical tools is because the variables used are latent variables. With SEM, latent variables can easily be measured with one measure. There is a mediating variable, whereby SEM this mediation problem is easier to solve and hypothesis 7 and hypothesis 8 can easily be proven. And the research sample that will be used as respondents is sufficient to be analyzed using SEM.

\section{FINDINGS AND DISCUSSION}

\section{Analysisof Structural EquationEquation}

The structural model analysis explaining the effect test between variables is presented in the following path diagram:

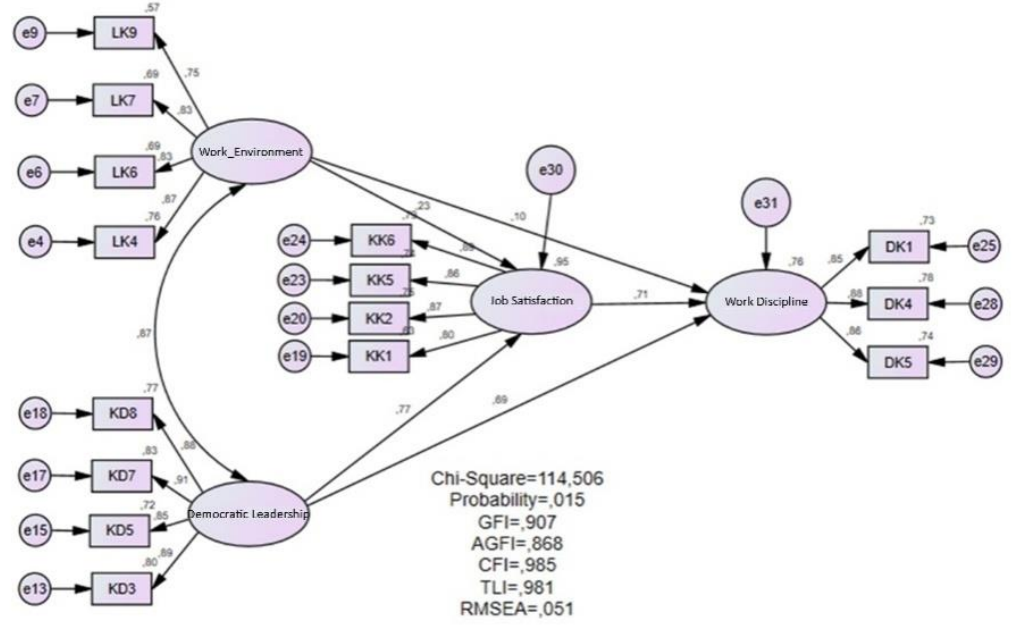

Figure 4. SEM Results

Based on Figure 4 above, it can be explained that the influence of each variable is the work environment and democratic leadership, on job satisfaction and work discipline.

\section{Hypothesis Testing and Discussion Descriptive Hypothesis Testing}

Descriptive hypothesis testing in this study resulted a mean value of work discipline of 3.93> 3.41. job satisfaction 4.09> 3.41, work environment 3.83>3.41, And democratic leadership is 3.98> 3.41. Furthermore, the descriptive hypothesis testing was carried out using a one-sample test with a cut off value of 3.41 with the following results: 
Table5.One-Sample Test

\begin{tabular}{|c|c|c|c|c|c|c|}
\hline & \multicolumn{6}{|c|}{ Test Value $=3.41$} \\
\hline & \multirow[t]{2}{*}{$\mathrm{t}$} & \multirow[t]{2}{*}{ df } & \multirow[t]{2}{*}{$\begin{array}{l}\text { Sig. (2- } \\
\text { tailed) }\end{array}$} & \multirow[t]{2}{*}{$\begin{array}{l}\text { Mean } \\
\text { Differenc } \\
\text { e }\end{array}$} & \multicolumn{2}{|c|}{$\begin{array}{l}95 \% \text { Confidence } \\
\text { Interval of the } \\
\text { Difference }\end{array}$} \\
\hline & & & & & Lower & Upper \\
\hline Work Environment & 6.383 & 138 & .000 & .38317 & .2645 & .5019 \\
\hline Democatic Leadership & \begin{tabular}{|l|}
10.13 \\
0
\end{tabular} & 138 & .000 & .60978 & .4908 & .7288 \\
\hline Job Satisfaction & 8.887 & 138 & .000 & .54504 & .4238 & .6663 \\
\hline Work Dicipline & 7.389 & 138 & .000 & .44345 & .3248 & .5621 \\
\hline
\end{tabular}

Source: Data Processed (2020)

Based on table 5 above, it can be seen that the test results of one sample test with a test value $=3.41$. The table above shows that the $\mathrm{df}$ value is 138 where this value is obtained from the value n-1 $(139-1=138)$. Values of Significance / Sig. ( 2 tailed) all are 0.000 or below 0.05 . With this, it can be concluded that testing the descriptive hypothesis (H1) resultsa proven hypothesis, where $\mathrm{Ha}$ is accepted and Ho is rejected. This shows that the variables of the work environment, democratic leadership, job satisfaction, and discipline are good. In other words, all variables have been implemented and implemented in the Public Works Office of Pidie Jaya District in good condition.

\section{Direct Hypothesis}

Based on SEM testing as shown in Figure 4 above, the following results are obtained

Table 6.Regression Weight Structural Equation Model

\begin{tabular}{|lll|l|l|l|l|}
\hline & & & Estimate & S.E. & C.R. & P \\
\hline Job Satisfaction & $<---$ & Work Environment & .214 & .091 & 2.356 & .018 \\
\hline Job Satisfaction & $<---$ & Democratic Leadership & .784 & .114 & 6.886 & $* * *$ \\
\hline Work Discipline & $<---$ & Job Satisfaction & .833 & .126 & 6.624 & $* * *$ \\
\hline Work Discipline & $<---$ & Work Environment & .090 & .154 & .586 & .558 \\
\hline Work Discipline & $<---$ & Democratic Leadership & .294 & .123 & 3.197 & $* * *$ \\
\hline
\end{tabular}

Source: Data Processed (2020)

By looking at the test results in table 6 above, the results of direct hypothesis testing can be explained as follows.

Testing the Influence of the Work Environment on Job Satisfaction of the Employee of the 


\section{International Journal of Business Management and Economic Review}

Vol. 4, No. 02; 2021

ISSN: 2581-4664

\section{Public Works Office of Pidie Jaya District}

The effect of the work environment on job satisfaction obtained a critical ratio (C.R) of 2.356 , which is greater than the cut-off value of 1.96 . The significance value or probability of 0.018 is smaller than 0.05 . The magnitude of the direct influence of the work environment on job satisfaction is 0.214 or $21.4 \%$. Thus the $\mathrm{H} 2$ hypothesis testing results in Ha2 accepted and $\mathrm{H} 02$ rejected, which means that the work environment has a significant effect on employee job satisfaction at the Public Works Office of Pidie Jaya District.

This shows that the better the working conditions, the employee job satisfaction will also increase. Employees who feel comfortable and satisfied with the conditions and facilities in the work environment tend to have high morale. The District Public Works Office needs to continue to pay attention to and further develop the factors related to the work environment so that employee job satisfaction can continue to be improved. These results support the research conducted by(Kurniawan et al., 2020), (Munandar et al., 2019), (Aulia et al., 2019), (Sasandaru, 2018), (Rafiie, Nasir, et al., 2018), (Husni et al., 2017), (Wani et al., 2018)(Sitinjak, 2018), and(Haedar, Saharuddin, \& Herlangga, 2015)which states that the work environment has a significant effect on job satisfaction.

A work environment is a daily place for employees to carry out their duties in running the government and providing services to the community as state servants. Based on field observations through distributing questionnaires, it is known that the working environment conditions at the Public Works Office of Pidie Jaya District are good. However, as a result of direct observation by researchers, there are still many things that need to be further improved and developed regarding the conditions of the work environment at the Public Works Office of Pidie Jaya District, both physically and non-physically. (Sedarmayanti, 2016), the work environment consists of a physical work environment and a non-physical work environment.

Therefore, in order to further improve employee job satisfaction, the Public Works Office of Pidie Jaya District as a public organization must always monitor and improve the conditions of its work environment both physically and non-physically so that a better and more comfortable work environment can continue. increase employee job satisfaction. As is well known, the level of employee job satisfaction is one of the important factors for an organization in achieving its goals, especially public organizations.

\section{Testing the Influence of Democratic Leadership on Job Satisfaction of Employee of the Public Works Office of Pidie Jaya District}

The influence of democratic leadership on job satisfaction obtained a critical ratio (C.R) of 6.886. This value is greater than the cut-off value of 1.96 . The significance or probability value of 0,000 is smaller than 0.05 . The magnitude of the direct influence of democratic leadership on job satisfaction is 0.784 or $78.4 \%$. Thus testing the hypothesis $\mathrm{H} 3$ results in Ha3 accepted and H03 rejected.

The results of this study are in line with the results of research conducted by(Mitang\& Kiha, 2019), (Dyczkowska \& Dyczkowski, 2018)(Angraini et al., 2016), and(Bhatti, Maitlo, Shaikh, Hashmi, \& Shaikh, 2012)who found that democratic leadership style has a positive and significant effect on job satisfaction. Within the Public Works Office of Pidie Jaya District, the democratic leadership style is very suitable to be used in running the wheels of government. This is due to this leadership style which always respects their subordinates and gives confidence to 


\section{International Journal of Business Management and Economic Review}

Vol. 4, No. 02; 2021

ISSN: 2581-4664

their subordinates in completing their duties so that it can have a positive impact on job satisfaction where employees who feel valued will certainly be more leverage and loyal to their work.

Within the Public Works Office of Pidie Jaya District, the democratic leadership style is very suitable to be used in running the wheels of government. This is because the attitude of a democratic leadership style never views employees only as an implementing tool in achieving work goals, but always respects employees, always provides motivation and work encouragement, and becomes role models for employees. to employees to be able to maximize the work and duties that have been responsible.Therefore, at the Public Works Office of Pidie Jaya District, the democratic leadership style is a factor that has a very big role in creating job satisfaction. Employees who feel valued and are not only considered as a means of carrying out their duties are very sure to have satisfaction with their work so that they directly increase loyalty to their work. Another thing that creates job satisfaction for Pidie Jaya DistrictPublic Works Office employees with a democratic leadership style is wherein every decision and policy making and task implementation strategy to achieve organizational goals as a public sector organization and the process of realizing all organizational targets that have been set at the beginning. years, the leader always involves all employees and is carried out by deliberation without prejudice to government regulations or laws.

\section{Testing the Influence of the Work Environment on Work Discipline of Employee of the Public Works Office of Pidie Jaya District}

The influence of the work environment on work discipline obtained a critical ratio (C.R) of 0.586 . This value is less than the cut-off value of 1.96. The significance or probability value of 0.558 is greater than 0.05 . The amount of direct influence of the work environment on work discipline is 0.09 . Thus testing the hypothesis $\mathrm{H} 4$ can be stated that $\mathrm{H} 04$ is accepted and Ha4 is rejected. This shows that the work environment variable has no effect on the work discipline of employees at the Public Works Office of Pidie Jaya District.

This shows that even though the work environment is already conducive, it cannot create work discipline for employees in the Public Works Office of Pidie Jaya District. The work discipline factor is more adhered to by other factors such as the rules that are enforced which have a positive and negative impact. The results of this study are not in line with the results of previous studies such as those conducted by(Putra \& Aprianti, 2020), (Inbar, Astuti, \& Sulistyo, 2018), (Oktaria \& Nugraheni, 2017), (Minarsih, 2017)where the results of their research show the work environment affects work discipline. In their research results, they also stated that the better the working environment, the better the work discipline of an employee.

Based on the field operations that the researchers carried out on the work environment, it can be concluded that the work environment does not affect employee work discipline because even though the working conditions of the Public Works Office of Pidie Jaya District are good, it is still far from the expectations of the employees themselves. This can be seen from the nonphysical conditions, especially where there are still fellow employees causing environmental pollution by smoking in the workspace so that other employees who do not smoke feel uncomfortable working in the workspace. For this reason, the leadership of the Pidie Jaya DistrictPublic Works Office must take firm action to eradicate this.

In terms of physical work environment conditions, the head of the Pidie Jaya DistrictPublic 


\section{International Journal of Business Management and Economic Review}

Vol. 4, No. 02; 2021

ISSN: 2581-4664

Works Office must also equip his work environment with monitoring devices such as CCTV in each workspace and the application of strict rules regarding work discipline. It is hoped that with this monitoring equipment and the application of strict rules regarding work discipline, it will make employees never absent from work during working hours and outside the needs of other outside services.

\section{Testing the Influence of Democratic Leadership on Employee Work Discipline at the Public Works Office of Pidie Jaya District}

The influence of democratic leadership on work discipline obtained a critical ratio (C.R) of 3.197, which is greater than the cut-off value of 1.96. The significance or probability value of 0,000 is smaller than 0.05 . The magnitude of the direct influence of democratic leadership on work discipline is 0.294 or $29.4 \%$. Thus testing the hypothesis H5 can be stated that Ha5 is accepted and H05 is rejected. This shows that the variable of democratic leadership has an effect on employee work discipline at the Public Works Office of Pidie Jaya District.

The results of this study are in line with the results of research conducted by(Astuti et al., 2019), (Kristianto, 2018), (Odhiambo, 2016), (Kiprob, 2015)who found results that democratic leadership has an effect on employee work discipline. To improve employee work discipline, a leader must be directly involved in the organizational group and respect all opinions expressed by his subordinates in order to achieve organizational goals. As expressed by(Suhardan, 2011)that the type of democratic leadership is not a dictator type, but the type who is directly involved in the midst of his group members. Democratic leaders always try to stimulate members to work productively to achieve common goals. This has an impact on employee work discipline where employees who have a high sense of responsibility will automatically increase their work discipline.

The democratic leadership style is able to apply the work discipline of the employees of the Public Works Office of Pidie Jaya District because as defined by previous researchers that the democratic leadership style in addition to involving employees as teamwork, this leadership style also always tries to develop personal capacity as a leader, and always tries to encourage employees for the better. Giving confidence in the delegation of job responsibilities to employees, automatically creates discipline for these employees so that they will be able to complete these job responsibilities properly. Work discipline is an important factor in carrying out duties and working, especially as a state servant who must always provide maximum service to the community and realize national development.

\section{Testing the Effect of Job Satisfaction on Work Discipline of Employee of the Public Works Office of Pidie Jaya District}

The effect of job satisfaction on work discipline has a critical ratio (C.R) of 6.624, which is greater than the cut-off value of 1.96. The significance or probability value of 0,000 is smaller than 0.05 . The magnitude of the direct effect of job satisfaction on work discipline is 0.833 or 83.3\%. Thus testing the hypothesis H6 can be stated that Ha6 is accepted and H06 is rejected. These results indicate that the job satisfaction variable has a direct effect on employee work discipline at the Public Works Office of Pidie Jaya District.

The results of this study are in line with the results of research conducted by(Hadian, 2019), (Nora, 2019), (Tiara \& Prakoso, 2018), (Ilahi et al., 2017), (Manik, 2017)which 


\section{International Journal of Business Management and Economic Review}

Vol. 4, No. 02; 2021

ISSN: 2581-4664

concluded that job satisfaction has a positive and significant effect on work discipline. Employees or human resources are the most important assets in the organization which are also partners of the organization in carrying out activities. Creating and increasing job satisfaction for employees on an ongoing basis can have an impact on employee work discipline so that the high work discipline of these employees will certainly have a positive impact on the service, especially the Public Works Office of Pidie Jaya District. The results of this study reject the results of research conducted by(Helmi, Yunus, \& Amri, 2019)wherein his research concluded that job satisfaction has no significant effect on work discipline.

\section{Indirect Hypothesis (Mediation)}

Testing the Influence of the Work Environment on Work Discipline of Employee of the Public Works Office of Pidie Jaya District in Mediation by Job Satisfaction

To find out the significant effect of mediating job satisfaction on the relationship of the work environment to work discipline by using the Sobel test assistance using the unstandardized estimate value as can be seen in the following figure:

\begin{tabular}{|c|c|c|c|c|}
\hline Input: & & Test statistic: & Std. Error: & $p$-value: \\
\hline$a 0.214$ & Sobel test: & 2.21564853 & 0.0804559 & 0.02671558 \\
\hline b 0.833 & Aroian test: & 2.19348574 & 0.08126882 & 0.0282724 \\
\hline$s_{a} 0.091$ & Goodman test: & 2.23849698 & 0.07963468 & 0.02518866 \\
\hline$s_{b} 0.126$ & Reset all & & Calculate & \\
\hline
\end{tabular}

Figure 5.Sobel Test Results of Hypothesis Mediation Effectof H7

The mediation hypothesis testing using the Sobel test for $\mathrm{H} 7$ as shown in Figure 5 above shows the results of the indirect influence between work environments on work discipline through job satisfaction with a statistical test value of 2.215> 1.96 and a P-value of $0.026<0,05$. So with this proves that the results of the $\mathrm{H} 7$ test prove that the indirect effect is a significant effect or $\mathrm{Ha} 7$ is accepted and $\mathrm{H} 07$ is rejected.

Based on the results of the significance calculation for path $\mathrm{C}$ 'using the Sobel test, it can be illustrated visually for all paths $\mathrm{A}, \mathrm{B}, \mathrm{C}$, and $\mathrm{C}^{\prime}$ to test the indirect effect of the work environment on work discipline through job satisfaction as shown in the following figure.

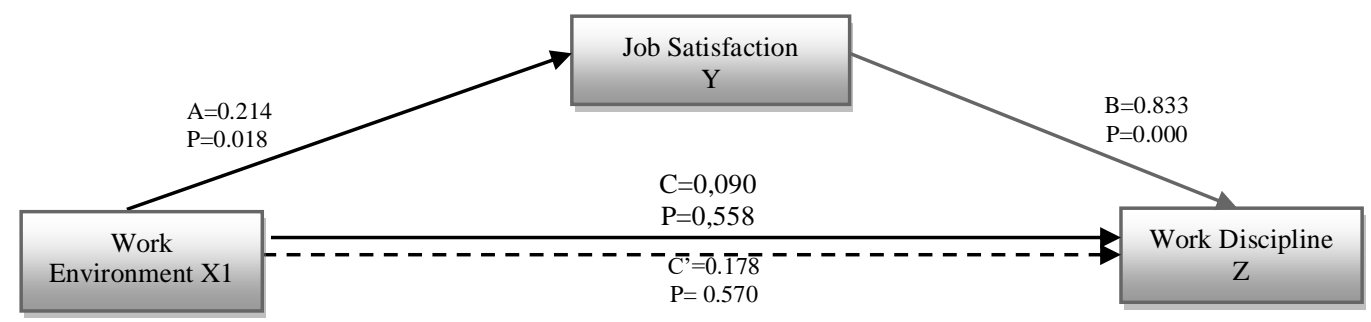

Figure 6.Chart of Hypothesis Mediation Effectof H7

Figure 6 above can be explained that the work environment variable has an effect on job 


\section{International Journal of Business Management and Economic Review}

Vol. 4, No. 02; 2021

ISSN: 2581-4664

satisfaction by explaining that the path coefficient $A$ has a value of $\beta=0.214$ and a value of $p=$ $0.018<0.05$. Path $B$ has a value of $\beta=0.833$ and $p$-value $=0.000<0.05$. From the value of path $\mathrm{A}$ and $\mathrm{B}$ it can be concluded that it is significant, while path $\mathrm{C}$ has a value of $\beta=0.090$ and a value of $p=0.558>0.05$ and $C$ 'has a value of $\beta=0.178(0.214 \times 0.833=0.178)$ and $p$-value $=$ $0.026<0,05$. This value indicates that the paths $\mathrm{A}, \mathrm{B}, \mathrm{C}$ and $\mathrm{C}$ 'are significant or often referred to as full mediation. So with this job satisfaction fully mediates the influence of the work environment on the work discipline of employees of the Public Works Office of Pidie Jaya District. The magnitude of the role of job satisfaction mediating the influence of the work environment on work discipline is 0.178 or $17.8 \%$.

From the results of the field survey that the researchers conducted, it was found that the average job satisfaction of the employees of the Public Works Office of Pidie Jaya District was good. Partially, it can also be seen that job satisfaction has an effect on employee work discipline because employees who have the desired job satisfaction can achieve good performance supported by high work discipline. However, the work environment directly does not affect employee performance. It is known that job satisfaction in this study acts as a full mediation between the influence of the work environment on employee work discipline. For this reason, the ranks of the Public Works Office need to further increase the job satisfaction factor through the policy direction implemented in the official environment. Because job satisfaction is a central factor in creating employee work discipline.

\section{Testing the Influence of Democratic Leadership on Employee Work Discipline at the Public Works Service of Pidie Jaya District in Mediation by Job Satisfaction}

To find out the significant effect of job satisfaction mediation on the relationship of democratic leadership to work discipline by using the Sobel test assistance using the unstandardized estimate value as can be seen in the following figure:

\begin{tabular}{|c|c|c|c|c|c|}
\hline & Input: & & Test statistic: & Std. Error: & $p$-value: \\
\hline$a$ & 0.784 & Sobel test: & 4.7660526 & 0.13702576 & 0.00000188 \\
\hline$b$ & 0.833 & Aroian test: & 4.74008009 & 0.13777657 & 0.00000214 \\
\hline & 0.114 & Goodman test: & 4.79245677 & 0.13627082 & 0.00000165 \\
\hline & 0.126 & Reset all & & Calculate & \\
\hline
\end{tabular}

Figure 7.Sobel Test Results of Hypothesis Mediation Effectof H8

Testing the mediation hypothesis using the Sobel test for $\mathrm{H} 8$ as shown in Figure 7 above shows the indirect influence between democratic leadership on work discipline through job satisfaction at the Public Works Office of Pidie Jaya District which has a statistical test value of 4.766> 1.96 and a P-value of 0.000 , which is less than 0.05 . So hereby proves that the results of the $\mathrm{H} 8$ test prove that the indirect effect is significant or $\mathrm{Ha} 8$ is accepted and $\mathrm{H} 08$ is rejected.

Based on the results of the significance calculation for path C 'using the Sobel test, it can be illustrated visually for all paths $\mathrm{A}, \mathrm{B}, \mathrm{C}$, and $\mathrm{C}^{\prime}$ to test the indirect effect of the work environment on work discipline through job satisfaction as shown in Figure 8 below. 


\section{International Journal of Business Management and Economic Review}

Vol. 4, No. 02; 2021

ISSN: 2581-4664

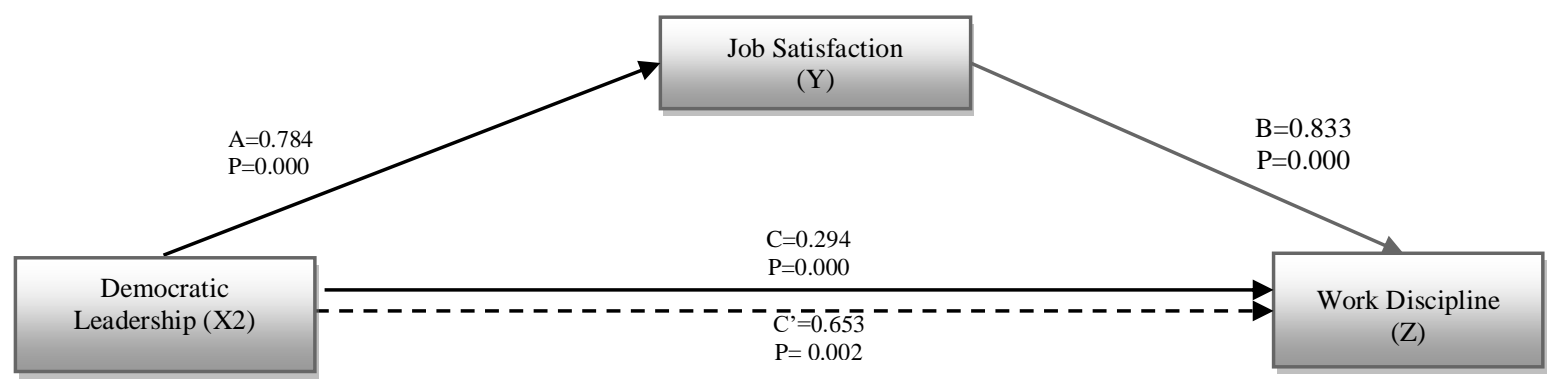

Figure 8. Chart of Hypothesis Mediation Effect of H8

Figure 8 above can be explained that the work environment variable has an effect on job satisfaction by explaining that the path coefficient $A$ has a value of $\beta=0.784$ and a value of $p=$ $0.000<0.05$. Path $B$ has a value of $\beta=0.833$ and $p$-value $=0.000<0.05$. Whereas for path $C$ has a value of $\beta=0.294$ and a value of $p=0.000<0.05$ and $C$ 'has a value of $\beta=0.653(0.784 x$ $0.833=0.653)$ and $\mathrm{p}$-value $=0.002<0.05$. This value indicates that pathways $\mathrm{A}, \mathrm{B}, \mathrm{C}$ and $\mathrm{C}$ 'are significant or often referred to as partial mediation. So for the results of indirect hypothesis testing, it can be said that job satisfaction mediates the influence of the work environment on employee work discipline at the Public Works Office of Pidie Jaya District. The magnitude of the influence of democratic leadership on work discipline through job satisfaction is 0.653 or $65.3 \%$.

It is known that job satisfaction in this study acts as a perfect mediator between the influence of democratic leadership on employee work discipline. The role of the leader is very big in increasing employee work discipline so that the organizational goals can be fully achieved. For this reason, in an effort to create disciplined employees, leaders must always pay attention to employee job satisfaction, leaders must also be able to meet employee needs both materially and immaterial. Inmaterial needs are more related to individual relationships by providing support, attention and encouragement so as to increase satisfactio006E.

\section{CONCLUSION AND RECOMMENDATION}

\section{Conclusion}

The results of the research at the Pijay District Government's Public Works Office, the following conclusions can be drawn:

1. Testing the descriptive hypothesis, namely the work environment, democratic leadership, job satisfaction and work discipline of the employee of the Public Works Office of Pidie Jaya District can be said to be good. This can be seen by using a one-sample test with a cutoff value of 3.41 where the result is that the probability value for all variables is 0.000 $<0.05$. 
Vol. 4, No. 02; 2021

ISSN: 2581-4664

2. The Goodness of Fit test has entered the required limit range so that the measurement model is considered to have met the requirements and can be said to be fit to proceed to the structural stage.

3. The results of direct hypothesis testing show that the work environment has a significant effect on job satisfaction (H2), democratic leadership has a significant effect on job satisfaction (H3), the work environment has no effect on work discipline (H4), democratic leadership has a significant effect on discipline. work (H5) and job satisfaction affect work discipline (H6).

4. The results of indirect hypothesis testing prove that job satisfaction does not mediate the effect of the work environment on employee work discipline (H7), and job satisfaction mediates (partial mediation) the effect of democratic leadership on employee work discipline (H8).

\section{RECOMMENDATION}

1. To improve the work discipline of the Pidie Jaya DistrictPublicWorksOffice employees, one of the factors that must be improved is to increase employee job satisfaction both materially and materially.

2. Even though the performance results produced by employees are already in the good category, nevertheless the level of employee work discipline must always be a priority for the attention of the office leadership. This is to prevent the lack of discipline in the work of employees, it is feared that in the end it will also have an impact on employee performance and future organizational performance.

3. In order to improve employee work discipline, the Head of the Public Works Office of Pidie Jaya District needs to install surveillance equipment in the form of CCTV in each workspace. So that by doing so, leaders can always monitor the level of work discipline of their employees. Monitoring the level of work discipline is not only sufficient with attendance, e-performance reports made by employees, and employee performance suggestions (SKP). But it also needs to be monitored directly. Because as is well known, there are still many employees who are absent during office hours, hanging out in coffee shops or canteens during working hours, as well as other things they do for personal gain during service hours.

\section{REFERENCES}

Agbozo, G. K., Owusu, I. S., Hoedoafia, M., \& Atakorah, Y. B. (2017). The Effect of Work Environment on Job Satisfaction: Evidence from the Banking Sector in Ghana. Journal of Human Resource Management, 5(1), 12-18. https://doi.org/10.11648/j.jhrm.20170501.12

Angraini, A. D., Syaharudin, M., \& Apriono, M. (2016). Pengaruh Gaya Kepemimpinan Demokratis, Lingkungan Kerja dan Motivasi Terhadap Kepuasan Kerja Karyawan Perusahaan Daerah Air Minum (PDAM) Bodowoso. SRA-Economic and Business Article, 1-8. Retrieved from http://repository.unej.ac.id/handle/123456789/64302

Astuti, F. P., Aunurrahman, \& Wahyudi. (2019). The Effect of Democratic Autocratic and Laissez-Faire (Free) Leadership Style of Kindergarten Headmaster toward Teacher Discipline Performance at Kindergartens in Southeast Pontianak District. Journal of 


\section{International Journal of Business Management and Economic Review}

Vol. 4, No. 02; 2021

ISSN: 2581-4664

Education, Teaching and Learning, 4(1), 130-138.

Aulia, M., Musnadi, S., \& Faisal. (2019). The Effect Of Competence, Workload And Work Environment On Employee Satisfaction And Its Implications On Employee Performance At PT. Bank Aceh Syariah's Operational Center Of Aceh Province, Indonesia. International Journal of Social Science \& Economic Research, 4(7), 5099-5110.

Bhatti, N., Maitlo, G. M., Shaikh, N., Hashmi, M. A., \& Shaikh, F. M. (2012). The Impact of Autocratic and Democratic Leadership Style on Job Satisfaction. International Business Research2, 5(2). https://doi.org/DOI:10.5539/ibr.v5n2p192

Chandra, T., \& Priyono. (2016). The Influence of Leadership Styles, Work Environment and Job Satisfaction of Employee Performance-Studies in the School of SMPN 10 Surabaya. International Education Studies, 9(1), 131-140. https://doi.org/10.5539/ies.v9n1p13

Dwinguspana, E., Sumari, A. D. W., \& Prihantoro, M. (2016). Pengaruh Kompensasi terhadap Kedisiplinan dan Kinerja Prajurit Batalyon Kavaleri 11/Serbu Kodam Iskandar Muda. Jurnal Pertahanan, 6(1), 169-191.

Dyczkowska, J., \& Dyczkowski, T. (2018). Democratic or Autocratic Leadership Style? Participative Management and its Links to rewarding Strategies and Job Satisfaction in SMEs. Athens Journal of Business and Economics, 4(2), 193-217.

Hadian, D. (2019). Effect Of Job Satisfaction On Work Discipline Mediated By Continuance Commitment. Jurnal Ekonomi, Bisnis \& Entrepreneurship, 13(1), 17-24. https://doi.org/10.5281/zenodo.3522777

Haedar, Saharuddin, \& Herlangga. (2015). Pengaruh Lingkungan Kerja dan Masa Kerja Terhadap Kepuasan Karyawan Pada PT. Hadji Kalla Palopo. Jurnal Manajemen, 2(1), 1022.

Hair, J. F., Hult, G. T. M., Ringle, C., \& Sarstedt, M. (2016). A Primer on Partial Least Squares Structural Equation Modeling (PLS-SEM) (2nd ed.). Thousand Oaks: Sage Publications, Inc.

Handoko, T. H. (2003). Manajemen edisi 2. Yogyakarta: BPFE.

Hasibuan, M. S. (2016). Buku Manajemen Sumber Daya Manusia (Revisi). Jakarta: Bumi Aksara.

Helmi, T., Yunus, M., \& Amri. (2019). The Effect Of Work Satisfaction On Organizational Commitment And Its Impact On Work Discipline Of Senior High School Teachers In Aceh Besar District, Aceh Province, Indonesia. International Journal of Social Science \& Economic Research, 4(6), 4501-4518.

Husni, Musnadi, S., \& Faisal. (2017). Pengaruh Lingkungan Kerja, Kompensasi Dan Motivasi Terhadap Kepuasan Kerja Serta Dampaknya Terhadap Loyalitas Kerja Pegawai Rutan Di Provinsi Aceh (Studi Kasus Pada Rutan Klas IIB Banda Aceh Dan Rutan Klas IIB Jantho). Jurnal Magister Manajemen, 1(1), 1-11.

Ilahi, D. K., Mukzam, M. D., \& Prasetya, A. (2017). Pengaruh Kepuasan Kerja terhadap Disiplin 


\section{International Journal of Business Management and Economic Review}

Vol. 4, No. 02; 2021

ISSN: 2581-4664

Kerja dan Komitmen Organisasional (Studi pada Karyawan PT. PLN (Persero) Distribusi Jawa Timur Area Malang). Jurnal Administrasi Bisnis (JAB), 44(1), 31-39.

Inbar, N. R. D., Astuti, E. S., \& Sulistyo, M. C. W. (2018). Pengaruh Lingkungan Kerja Terhadap Disiplin Kerja Dan Semangat Kerja Karyawan (Studi Pada Karyawan PDAM Kota Malang). Jurnal Administrasi Bisnis, 58(1), 84-92.

Judge, T. A., \& Mueller, J. D. K. (2012). Job Attitudes. Annual Review of Psychology2, 63, 341367. https://doi.org/https://doi.org/10.1146/annurev-psych-120710-100511

Kiprob, B. R. (2015). Influence Of Headteachers' Leadership Styles On Students' Discipline In Public Secondary Schools In Kericho Sub-County, Kericho County, Kenya. University of Nairobi.

Kobat, Y., Sijabat, F. N., \& Safrita. (2018). Pengaruh Gaya Kepemimpinan Demokratis dan Otoriter terhadap Prestasi Kerja Pegawai Negeri Sipil (PNS) Sekretariat Dewan Perwakilan Rakyat Aceh. SIMEN (Akuntansi Dan Manajemen) STIES, 9(2), 19-36.

Kristianto, A. (2018). Analisis Penerapan Gaya Kepemimpinan dan Kondisi Lingkungan Kerja terhadap Disiplin Kerja Karyawan Perspektif Etika Kerja Islam (Studi pada PT. Bank Pembiayaan Rakyat Syariah (BPRS) Mitra Agro Usaha Bandar Lamplung. Universitas Islam Negeri Raden Intan, Lampung.

Kular, S., Gatenby, M., \& Rees, C. (2008). Employee Engagement: A Literature Review. Inggris: Kingston Business School.

Kurniawan, F., Mukhlis, \& Musnadi, S. (2020). The Effect of Work Environment and Service Facilities in Polres Pidie towards OCB Members with Work Satisfaction as a Mediating Variable. International Journal of Research in Business and Technology, 12(1), 149-156. Retrieved from https://journals.techmindresearch.com/index.php/ijrbt

Mangkunegara, A. P. (2013). Manajemen Sumber Daya Manusia Perusahaan. Bandung: Remaja Rosdakarya.

Manik, S. (2017). Pengaruh Kepuasan Kerja Terhadap Disiplin Kerja Pegawai Kantor Camat Pendalian IV Koto Kabupaten Rokan Hulu. International Journal of Social Science and Business, 1(4), 257-264.

Minarsih, M. M. (2017). Pengaruh Gaya Kepemimpinan, Lingkungan Kerja Dan Kompensasi Terhadap Disiplin Dan Kinerja Karyawan (Studi Kasus Pada Karyawan CV. Premier Semarang ). Jurnal Ekonomi Dan Bisnis Kontemporer, 3(2).

Mitang, B. B., \& Kiha, E. K. (2019). Analisis Pengaruh Gaya Kepemimpinan Demokratis dan Kompensasi terhadap Kinerja Pegawai dengan Kepuasan Kerja sebagai Variabel Intervening (Studi Kasus pada Pegawai Dinas Kesehatan Kabupaten Timor Tengah Utara). Inspirasi Ekonomi, 4(2), 41-60.

Mukhalipi, A. (2018). Employee Discipline Enhances Employee Engagement: An Affective Shift Model Perspective -A Literature Review. Texila International Journal of Management, 4(1), 1-11. https://doi.org/10.21522/TIJMG.2015.04.01.Art006 


\section{International Journal of Business Management and Economic Review}

Vol. 4, No. 02; 2021

ISSN: 2581-4664

Munandar, A., Musnadi, S., \& Sulaiman, S. (2019). The Effect of Work Stress, Work Load and Work Environment on Job Satisfaction And It's Implication on The Employee Performance of Aceh Investment And One Stop Services Agency. International Graduate Conference (IGC), (Oktober). https://doi.org/10.4108/eai.3-10-2018.2284357

Nora, M. E. (2019). Pengaruh Kepuasan Kerja terhadap Disiplin Kerja pada Pegawai Balai Veteriner Medan. Sumatera Utara University.

Northouse, P. G. (2013). Leadership: Theory and Practice (6th ed.). Thousand Oaks: Sage Publications, Inc.

Novitasari, P. (2017). Analisis Pengaruh Komunikasi, Gaya Kepemimpinan, Lingkungan Kerja, Dan Disiplin Kerja Terhadap Kinerja Pegawai Dinas Kesehatan Provinsi Jawa Tengah. Universitas Dian Nuwsantoro.

Odhiambo, O. B. (2016). Influence Of Principals' Leadership Styles On Students' Discipline In Public Secondary Schools In Kikuyu Sub County, Kenya. University of Nairobi.

Oktaria, R. A., \& Nugraheni, R. (2017). Pengaruh Lingkungan Kerja, Kepuasan Kompensasi, Dan Motivasi Kerja Terhadap Disiplin Kerja Pegawai Pada Pdam Tirta Moedal Kota Semarang. Dipenogoro Journal of Management, 6(3), 1-10.

Pawirosumarto, S., Sarjana, P. K., \& Gunawan, R. (2017). The effect of work environment, leadership style, and organizational culture towards job satisfaction and its implication towards employee performance in Parador Hotels and Resorts, Indonesia. International Journal of Law and Management, 59(6), 1337-1358. https://doi.org/10.1108/IJLMA-10-2016-0085

Potu, A. (2013). Kepemimpinan, Motivasi, Dan Lingkungan Kerja Pengaruhnya Terhadap Kinerja Karyawan Pada Kanwil Itjen Kekayaan Negara Suluttenggo Dan Maluku Utara Di Manado. Jurnal EMBA, 1(4), 1208-1218. https://doi.org/https://doi.org/10.35794/emba.v1i4.2894

Putra, A., \& Aprianti, K. (2020). Pengaruh Lingkungan Kerja Terhadap Disiplin Kerja Pegawai Kantor Camat Lambitu Kabupaten Bima. SULTANIST: Jurnal Manajemen Dan Keuangan, 8(1), 19-27. https://doi.org/10.37403/sultanist.v8i1.184

Rafiie, D. S., Azis, N., \& Idris, S. (2018). Pengaruh kompetensi, gaya kepemimpinan, budaya kerja dan lingkungan kerjaterhadap kepuasan kerja pegawai dan dampaknya terhadap kinerja pegawai Kantor Kementerian Agama Kabupaten Aceh Barat. Jurnal Magister Manajemen, 2(1), 36-45.

Rafiie, D. S., Nasir, \& Sofyan. (2018). Pengaruh Kompetensi, Gaya Kepemimpinan, Budaya Kerja dan Lingkungan Kerja Terhadap Kepuasan Kerja Pegawai dan Dampaknya Terhadap Kinerja Pegawai Kantor Kementerian Agama Kabupaten Aceh Barat. Jurnal Magister Manajemen, 1(1).

Robbins, S. P., \& Coulter, M. (2016). Manajemen (ed. 13). Jakarta: Erlangga.

Robbins, S. P., Coulter, M. A., \& Cenzo, D. A. De. (2019). Fundamentals of Management (11th ed.). London: Pearson. 


\section{International Journal of Business Management and Economic Review}

Vol. 4, No. 02; 2021

ISSN: 2581-4664

Robbins, S. P., \& Judge, T. A. (2012). Organizational Behavior (15th ed.; S. Yagan, Ed.). San Diego: Pearson.

Sari, R. F., Siburian, T. A., \& Wau, Y. (2017). The Effect Of Work Discipline, Job Satisfaction And Work Motivation Towards Teacher Organizational Commitment In Smp Negeri Of Medan Kota District. IOSR Journal of Research \& Method in Education (IOSR-JRME), 7(5), 45-54.

Sasandaru, C. R. (2018). Pengaruh Gaya Kepemimpinan, Lingkungan Kerja dan Disiplin Kerja terhadap Kinerja Karyawan Dengan Kepuasan Kerja sebagai Variabel Intervening (Studi Kasus PT. BTN Syariah Kantor Cabang Semarang). Institut Agama Islam Negeri Salatiga.

Sedarmayanti. (2016). Manajemen sumber daya manusia reformasi birokrasi dan manajemen pegawai negeri sipil (5th ed.). Bandung: Repika Aditama.

Sinungan, M. (2018). Produktivitas: Apa Dan Bagaimana (Ed 2 Cet10). Jakarta: Bumi Aksara.

Sitinjak, L. N. (2018). Pengaruh Lingkungan Kerja terhadap Kepuasan Kerja Karyawan (Studi pada Karyawan PT. Mitra Pinasthika Mustika Rent Tanggrang Selatan. Jurnal Administrasi Bisnis (JAB), 60(2), 162-168.

Soetrisno, E. (2016). Manajemen Sumber Daya Manusia (Cetakan Ke). Jakarta: Prenada Media Gorup.Suhardan, H. D. (2011). Manajemen Pendidikan. Bandung: Alfabeta.

Suryaningsih. (2017). Hubungan Antara Gaya Kepemimpinan Demokratis dan Kepuasan Kerja dengan Kualitas Pelayanan di Bagian Umum Sekretaris Daerah Kabupaten Karimun. Universitas Terbuka, Jakarta.

Suwuh, M. (2015). The Influence Of Leadership Style, Motivation, And Work Discipline On Employee Performance At Bank Sulut Kcp Likupang. Jurnal EMBA, 3(4), 611-619.

Thoha, M. (2012). Perilaku Organisasi : Konsep Dasar dan Aplikasinya. Jakarta: Rajawali Pers.

Tiara, V. R., \& Prakoso, H. (2018). Pengaruh Kepuasan Kerja Terhadap Disiplin Kerja Karyawan Bagian Produksi Toys PT X Sukabumi. SPESIA Seminar Penelitian Sivitas Akademik Unisba, 200-2005. https://doi.org/http://dx.doi.org/10.29313/.v0i0.9412

Wani, C. E., Adam, M., \& Majid, M. S. A. (2018). The Mediated Effect of Job Satisfaction on the Relationships between Leadership Effectiveness, Organizational Support, Working Environment and Ability: The Case of State-Owned Electricity Company in Indonesia. IOSR Journal of Business and Management (IOSR-JBM), 20(9), 68-74. https://doi.org/https://doi.org/10.9790/487X-2009066874

Yugusna, I., Fathoni, A., \& Haryono, A. T. (2016). Pengaruh Gaya Kepemimpinan Demokratis dan Lingkungan Kerja terhadap Kinerja dan Kedisiplinan Karyawan (Studi Empiris pada Perusahaan SPBU 44.501.29 Randu Garut Semarang). Journal Of Management, 2(2).

Zainal, V. R. (2015). Manajemen Sumber Daya Manusia Untuk Perusahaan: Dari Teori ke Praktik. In Jakarta: PT. Raja Grafindo Persadi (Edisi Keti). Depok: PT. Rajagrafindo Persada. 